\title{
IMMUNOLOGICAL STUDY OF CORONARY ARTERY DISEASE ASSOCIATED WITH DIABETES MELLITUS TYPE II IN IRAQI PATIENTS
}

\author{
MUNDHER JABBAR AL-OKHEDI ${ }^{1}$, MOHAMMED QAIS AL-ANI ${ }^{2 *}$, MARRIB N RASHEED ${ }^{3}$
}

${ }^{1}$ Department of Biology, College of Education for Pure Sciences, University of Anbar, Ramadi, Iraq. ${ }^{2}$ Department of Biology, College of Science, University of Anbar, Ramadi, Iraq. ${ }^{3}$ Department of Genetic Engineering, Institute of Genetic Engineering and Biotechnology for Post Graduate Studies, University of Baghdad, Baghdad, Iraq. Email: sc.drmohammedqais1975@uoanbar.edu.iq

Received: 02 June 2018, Revised and Accepted: 01 August 2018

ABSTRACT

Objective: The objective of this study was to investigate the association between proinflammatory cytokines in special, the interleukin-6 (IL-6), and insulin-like growth factor (IGF-1) levels in coronary artery disease (CAD) and type 2 diabetes mellitus (T2DM).

Methods: This study was conducted from November 2017 to March 2018 in Anbar, Iraq. We studied a total of 90 individuals (46 men and 44 women) aged between 20 and 87 years. The samples were divided into four groups: CAD patients $(n=23), T 2 D M$ patients $(n=23)$, coronary artery disease and type 2 diabetes together in the same patient $(\mathrm{n}=23)$, and control group $(\mathrm{n}=21)$. The concentrations of IL- 6 and IGF-1 were determined using a commercially available enzyme-linked immune sorbent assay.

Results: The results of the present study showed that there were elevated serum levels of IL- 6 and low levels of IGF-1 in all the tested groups, compared with the control. The difference was statistically significant at $\mathrm{p}<0.05$. The results showed a positively correlated between IL- 6 and IGF- 1 in the CAD group and T2DM group, while it was a negative correlation between serum levels of IL- 6 and IGF-1 in the T2DM+CAD group.

Conclusion: Elevated levels serum of IL-6 predicts the development of CAD and T2DM. These data support a possible role for inflammation in diabetogenesis and complication of the cardiovascular disease. There is an inverse relationship between the levels serum of IGF-1 and increased risk of CAD and development of T2DM.

Keywords: Interleukin-6, Insulin-like growth factor, Coronary artery disease, Type 2 diabetes mellitus.

(c) 2018 The Authors. Published by Innovare Academic Sciences Pvt Ltd. This is an open access article under the CC BY license (http://creativecommons. org/licenses/by/4. 0/) DOI: http://dx.doi.org/10.22159/ajpcr.2018.v11i12.27620

\section{INTRODUCTION}

Coronary artery disease (CAD) and type 2 diabetes mellitus (T2DM) are the common health problems. These two diseases are one of the main causes of mortality around the world. In 2010, approximately 8.3 million people were died due to these diseases, almost one in six deaths worldwide. In the last decades, the prevalence of CAD and T2DM has an increased greatly [1]. Although the main cause for this increase remains unclear, the primary reason maybe is chronic low-grade inflammation and an activation of the innate immunity system [2].

The main cause of CAD is atherosclerosis, which occurs because of plaque buildup which leads to narrowing bloodstream of the coronary arteries that supply the myocardium with blood. This problem leads to lack of blood flow and shows symptom ischemia [3]. CAD is considered as a chronic and very common disorder with conventional and genetic danger factors. The conventional risk factors for CAD involve obesity, age, dyslipidemia, gender, smoking, hypertension, and diabetes. These factors act autonomously or in concert together to increase the danger of the CAD [4].

The term T2DM describes insulin secretion deficiency due to pancreatic $\beta$-cell dysfunction and impaired insulin receptors and insulin action [5]. T2DM develops due to the collective action of both insufficient insulin secretion and insulin resistance (IR) [6]. There are many factors increased the risk of T2DM such as a family history of diabetes and environmental factors [7,8]. Other studies have shown that there was a strong association between type 2 diabetes, CAD, and inflammatory markers. The increase of macrophages in adipose tissue, the predominant presence of peripheral mononuclear cells, and apoptotic $\beta$-cells by themselves may be the causes of inflammation present in T2DM since they create the mediators of the inflammatory processes, i.e., cytokines [9]. Interleukin-6 (IL-6) is a multifunctional cytokine that owns a broad range of activities. The main role for IL-6 in inflammatory is hematopoiesis and regulating the immune response. There are several cells that are responsible of producing IL-6 including $\mathrm{T}$ and $\mathrm{B}$ cells, endothelial cells, monocytes/macrophages, fibroblasts, and adipocytes $[10,11]$.

Increase generation of IL- 6 involves the progression of CAD because raised IL-6 levels are associated with increased risk and ferocity of CAD [12]. Inflammatory biomarkers are one of the signs that predict the onset of cardiovascular events [13].

The important value of these markers, including (IL-6), has been demonstrated for patients suffering from CAD [14]. In addition, several studies have been shown high levels of IL-6 in insulin-resistant states such as obesity, impaired glucose tolerance (IGT), and T2DM [15]. As other studies have shown, a strong relationship found between IL- 6 and levels of glucose was an important predictor of type 2 diabetes in at-risk individuals. Inability in glucose control and its link with inflammation in diabetes mellitus cause CAD, decline lung functions, and cause cardiovascular disorder [16].

The insulin-like growth factor 1 (IGF-1) is a small peptide of $7.6 \mathrm{kDa}$, which is composed of 70 amino acids and similar $50 \%$ structure of insulin [17]. IGF-1 plays important roles in controlling proliferation, metabolism, differentiation, and cell survival. It is producing by the liver in response to growth hormone. However, other tissues also a synthesis of IGF-1, which works as a paracrine hormone and autocrine. At the cellular grade, IGF-1 can act in another subcellular compartment. It is, therefore, necessary to understand the complication of IGF-1 signaling and its role in the onset and progress of disease. Particularly in the 
heart, several cellular processes can be regulated by IGF-1 including apoptosis, aging, metabolism, growth, and autophagy $[18,19]$. There is a study suggest decreasing IGF-1 levels to be a sign of diabetes [20].

There is some contradiction in the findings of the studies; one study found a positive association with reducing serum IGF-1 [21] while the another study did not find an association [22]. There is negatively relationship between serum IGF-1 levels and risk of developing CAD [18]. A low level of serum IGF-1 is associated with a risen risk of CAD and has been utilized as a signal for ischemic. Similarly, elderly patients showing low serum IGF-1 levels with an increased risk of heart failure and ischemic stroke $[19,23]$.

\section{METHODS}

This study was conducted from November 2017 to March 2018 in Anbar, Iraq. We studied a total of 90 subjects ( 46 men and 44 women) aged between 20 and 87 years divided into four groups: CAD patients ( $n=23)$, T2DM patients $(\mathrm{n}=23)$, coronary artery disease and type 2 diabetes together in the same patient ( $\mathrm{n}=23)$, and control group $(\mathrm{n}=21)$ who had no evidence of CAD or T2DM. Venous blood samples of all the groups (patients and control) were drawn using plastic disposable syringes placed into gel tubes and separated by centrifugation at $3000 \mathrm{rpm}$ for $15 \mathrm{~min}$. After that, serum was decanted and stored at $-20^{\circ} \mathrm{C}$ until assayed. The concentrations of IL- 6 and IGF-1 were determined using a commercially available enzyme-linked immune sorbent assay (ELISA) based on biotin double antibody sandwich technology, ELISA kit (Gen Asia) GA-E0130HM and GA-E0143HM, respectively, according to the manufacturer's instructions. The range of detection was $0-2500 \mathrm{pg} / \mathrm{ml}$ for IL-6 and $0.1-40 \mathrm{ng} / \mathrm{ml}$ for IGF-1.

\section{RESULTS}

Table 1 shows the serum levels of IL- 6 in different groups of patients. Serumlevels of IL- 6 in patients with CAD $(310.30 \pm 125.96 \mathrm{pg} / \mathrm{ml} ; \mathrm{p}<0.05)$ and T2DM+CAD $(479.87 \pm 216.56 \mathrm{pg} / \mathrm{ml} ; \mathrm{p}<0.05)$ were increased compared with the control $(137.38 \pm 35.49 \mathrm{pg} / \mathrm{ml})$. The difference was statistically significant at $\mathrm{p}<0.05$. As for the serum level of IL- 6 was also analyzed in patients with T2DM and although the values were higher in this group $(216.83 \pm 80.60 \mathrm{pg} / \mathrm{ml}$; $\mathrm{p}<0.05)$, compared with the control $(137.38 \pm 35.49 \mathrm{pg} / \mathrm{ml})$, the difference was not statistically considerable.

However, Table 2 appears the low levels of IGF- 1 in the T2DM, CAD, and $\mathrm{T} 2 \mathrm{DM}+\mathrm{CAD}$ groups compared with those in controls $(12.09 \pm 4.77$ vs. $28.81 \pm 4.84 \mathrm{ng} / \mathrm{ml} ; \mathrm{p}<0.05,13.74 \pm 4.65$ vs. $28.81 \pm 4.84 \mathrm{ng} / \mathrm{ml} ; \mathrm{p}<0.05$, and $11.57 \pm 4.19$ vs. $28.81 \pm 4.84 \mathrm{ng} / \mathrm{ml} ; \mathrm{p}<0.05$, respectively). This difference was statistically worthy.

Regarding the study of the effect of sex on levels of serum IL-6 and IGF-1, the t-test showed no significant differences in the values of serum IL-6 and IGF-1 between the males and females of the T2DM group where the values in males are $218.44 \pm 86.54 \mathrm{pg} / \mathrm{ml}$ and $14.11 \pm 5.18 \mathrm{ng} / \mathrm{ml} ; \mathrm{p}<0.05$, respectively, and in the females are $215.79 \pm 79.90 \mathrm{pg} / \mathrm{ml}$ and $10.79 \pm 4.15 \mathrm{ng} / \mathrm{ml} ; \mathrm{p}<0.05$, consecutive. On the other hand, there were expressive differences in the values of serum IL-6 and IGF-1 in both genders in the CAD group where the values in males are $361.62 \pm 112.04 \mathrm{pg} / \mathrm{ml}$ and $15.62 \pm 4.44 \mathrm{ng} / \mathrm{ml} ; \mathrm{p}<0.05$, successive, and in the females are $243.60 \pm 115.33 \mathrm{pg} / \mathrm{ml}$ and $11.30 \pm 3.86 \mathrm{ng} / \mathrm{ml}$; $\mathrm{p}<0.05$, sequent. In addition, there were worthy differences in the values of serum IL- 6 between males and females in the DM+CAD group. The values in the males were $381.36 \pm 212.31 \mathrm{pg} / \mathrm{ml} ; \mathrm{p}<0.05$ and females were $570.17 \pm 184.98 \mathrm{pg} / \mathrm{ml} ; \mathrm{p}<0.05$, but there were no significant differences in the values of serum IGF-1, the values in the males are $12.73 \pm 4.29 \mathrm{ng} / \mathrm{ml} ; \mathrm{p}<0.05$ and in the females are $10.50 \pm 3.97 \mathrm{ng} / \mathrm{ml}$; $\mathrm{p}<0.05$ (Table 3).

Turning to study of the relationship of hypertension with levels of serum IL- 6 and IGF-1, there are differences in the mean values of serum IL- 6 and IGF- 1 in all the tested groups. Serum levels of IL- 6 and IGF- 1 in
Table 1: Serum levels of IL-6 in all the tested groups

\begin{tabular}{llll}
\hline \multirow{2}{*}{ Groups } & \multicolumn{2}{l}{$\mathbf{I L - 6}(\mathbf{p g} / \mathbf{m l})$} & $\mathbf{p}<\mathbf{0 . 0 5}$ \\
\cline { 2 - 4 } & $\mathbf{n}$ & $\mathbf{M e a n} \pm \mathbf{S D}$ & $\mathrm{a}$ \\
& 23 & $216.83 \pm 80.60$ & $\mathrm{~b}$ \\
T2DM & 23 & $310.30 \pm 125.96$ & $\mathrm{c}$ \\
CAD & 23 & $479.87 \pm 216.56$ & $\mathrm{a}$ \\
Control & 21 & $137.38 \pm 35.49$ & \\
Total & 90 & $289.40 \pm 183.59$ & \\
\hline
\end{tabular}

T2DM: Type 2 diabetes mellitus, CAD: Coronary artery disease, SD: Standard deviation, IL-6: Interleukin-6

Table 2: Serum levels of the IGF-1 in all the tested groups

\begin{tabular}{llll}
\hline Groups & N & IGF-1 (ng/ml) & $\mathbf{p}<\mathbf{0 . 0 5}$ \\
& & Mean \pm SD & \\
\hline T2DM & 23 & $12.09 \pm 4.77$ & $\mathrm{a}$ \\
CAD & 23 & $13.74 \pm 4.65$ & $\mathrm{a}$ \\
CAD+T2DM & 23 & $11.57 \pm 4.19$ & $\mathrm{a}$ \\
Control & 21 & $28.81 \pm 4.84$ & $\mathrm{~b}$ \\
Total & 90 & $16.28 \pm 8.34$ & \\
\hline
\end{tabular}

T2DM: Type 2 diabetes mellitus, CAD: Coronary artery disease, SD: Standard deviation, IGF-1: Insulin-like growth factor

Table 3: The association between serum levels of IL-6, IGF-1, and gender in all the tested groups

\begin{tabular}{lllll}
\hline Groups & $\mathbf{n}$ & Mean \pm SD & t-test & p value \\
\hline $\begin{array}{l}\text { T2DM } \\
\text { IL-6 }\end{array}$ & & & & \\
$\quad$ Male & 9 & $218.44 \pm 86.54$ & 0.075 & 0.941 \\
$\quad$ Female & 14 & $215.79 \pm 79.90$ & & \\
IGF-1 & & & & \\
$\quad$ Male & 9 & $14.11 \pm 5.18$ & 1.702 & 0.104 \\
$\quad$ Female & 14 & $10.79 \pm 4.15$ & & \\
CAD & & & & \\
$\quad$ IL-6 & & & & \\
$\quad$ Male & 13 & $361.62 \pm 112.04$ & 2.473 & 0.022 \\
$\quad$ Female & 10 & $243.60 \pm 115.33$ & & \\
IGF-1 & & & & \\
$\quad$ Male & 13 & $15.62 \pm 4.44$ & 2.440 & 0.024 \\
$\quad$ Female & 10 & $11.30 \pm 3.86$ & & \\
T2DM+CAD & & & & \\
$\quad$ IL-6 & & & & \\
$\quad$ Male & 11 & $381.36 \pm 212.31$ & -2.279 & 0.033 \\
$\quad$ Female & 12 & $570.17 \pm 184.98$ & & \\
IGF-1 & & & & \\
$\quad$ Male & 11 & $12.73 \pm 4.29$ & 1.294 & 0.210 \\
$\quad$ Female & 12 & $10.50 \pm 3.97$ & & \\
\hline
\end{tabular}

The t-test is significant at the 0.05 level or less. T2DM: Type 2 diabetes mellitus, SD: Standard deviation, CAD: Coronary artery disease, IL-6: Interleukin-6, IGF-1: Insulin-like growth factor

patients that do not suffer from hypertension with the T2DM group are $223.38 \pm 85.22 \mathrm{pg} / \mathrm{ml}$ and $11.85 \pm 5.11 \mathrm{ng} / \mathrm{ml} ; \mathrm{p}<0.05$, consecutive. While in patients that suffer from hypertension are $208.30 \pm 77.82 \mathrm{pg} / \mathrm{ml}$ and $12.40 \pm 4.53 \mathrm{ng} / \mathrm{ml}$, respectively. As for the patients that do not suffer from hypertension with CAD group, the values are $358.67 \pm 134.19 \mathrm{pg} / \mathrm{ml}$ and $13.50 \pm 5.75 \mathrm{ng} / \mathrm{ml} ; \mathrm{p}<0.05$, successive, and in patients that suffer from hypertension are $293.24 \pm 122.49 \mathrm{pg} / \mathrm{ml}$ and $13.82 \pm 4.41 \mathrm{ng} / \mathrm{ml}$; $\mathrm{p}<0.05$, respectively. In addition, the values of the levels serum IL- 6 and IGF-1 in the patients that do not suffer from hypertension with type 2 diabetes and CADs T2DM+CAD group were $443.20 \pm 275.09 \mathrm{pg} / \mathrm{ml}$ and $13.40 \pm 3.85 \mathrm{ng} / \mathrm{ml} ; \mathrm{p}<0.05$, successive, and in persons that suffer from hypertension were $490.06 \pm 205.86 \mathrm{pg} / \mathrm{ml}$ and $11.06 \pm 4.24 \mathrm{ng} / \mathrm{ml}$; $\mathrm{p}<0.05$, consecutive. Although there are differences in the mean values 
and standard deviation values of serum IL-6 and IGF-1, the difference was not statistically significant (Table 4).

\section{Correlations among the IL-6 and IGF-1}

As shown in Fig. 1, IL-6 was positively correlated with serum levels of IGF-1in the T2DM group ( $\mathrm{r}=0.019, \mathrm{p}<0.05)$, although there was positively correlated, it is not statistically considerable at $\mathrm{p}<0.05$ (Table 5).

A positive correlation was also observed between serum levels of IL-6 and IGF-1 in the CAD group $(\mathrm{r}=0.266 \mathrm{p}<0.05)$ as shown in Fig. 2. It was statistically significant at $\mathrm{p}<0.05$ (Table 5). While it was a negative correlation between serum levels of IL-6 and IGF-1 in the T2DM+CAD group $(r=0.070 \mathrm{p}<0.05)$ as shown in (Fig. 3). It is not statistically expressive at $\mathrm{p}<0.05$.

\section{DISCUSSION}

CAD is a disorder characterized by atherosclerosis of the heart arteries (blood vessels responsible for supplying the heart with blood). The slowly narrowing the vessel walls that transport blood to the heart its major reason for this disease, by lipid plaques that lead to show

Table 4: The relationship of hypertension with levels of serum IL-6 and IGF-1 in all the tested groups

\begin{tabular}{|c|c|c|c|c|}
\hline Groups & $\mathbf{n}$ & Mean \pm SD & t-test & p value \\
\hline \multicolumn{5}{|l|}{ T2DM } \\
\hline \multicolumn{5}{|l|}{ IL-6 } \\
\hline Normal & 13 & $223.38 \pm 85.22$ & 0.437 & 0.667 \\
\hline Abnormal & 10 & $208.30 \pm 77.82$ & & \\
\hline \multicolumn{5}{|l|}{ IGF-1 } \\
\hline Normal & 13 & $11.85 \pm 5.11$ & -0.270 & 0.790 \\
\hline Abnormal & 10 & $12.40 \pm 4.53$ & & \\
\hline \multicolumn{5}{|l|}{ CAD } \\
\hline \multicolumn{5}{|l|}{ IL-6 } \\
\hline Normal & 6 & $358.67 \pm 134.19$ & 1.099 & 0.284 \\
\hline Abnormal & 17 & $293.24 \pm 122.49$ & & \\
\hline \multicolumn{5}{|l|}{ IGF-1 } \\
\hline Normal & 6 & $13.50 \pm 5.75$ & -0.143 & 0.888 \\
\hline Abnormal & 17 & $13.82 \pm 4.41$ & & \\
\hline \multicolumn{5}{|l|}{$\mathrm{T} 2 \mathrm{DM}+\mathrm{CAD}$} \\
\hline \multicolumn{5}{|l|}{ IL-6 } \\
\hline Normal & 5 & $443.20 \pm 275.09$ & -0.420 & 0.679 \\
\hline Abnormal & 18 & $490.06 \pm 205.86$ & & \\
\hline \multicolumn{5}{|l|}{ IGF-1 } \\
\hline Normal & 5 & $13.40 \pm 3.85$ & 1.114 & 0.278 \\
\hline Abnormal & 18 & $11.06 \pm 4.24$ & & \\
\hline
\end{tabular}

The t-test is significant at the 0.05 level or less. IL-6: Interleukin-6, IGF-1: Insulin-like growth factor, SD: Standard deviation

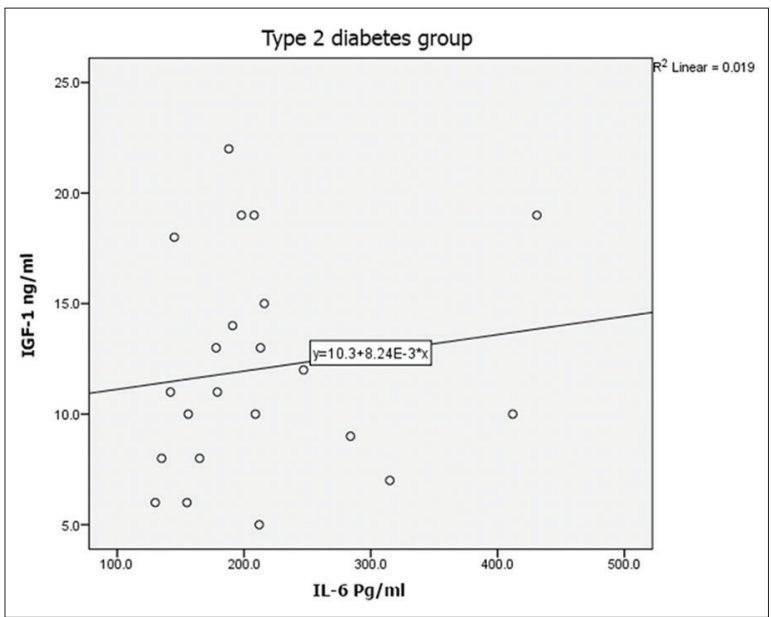

Fig. 1: Correlation between interleukin-6 and insulin-like growth factor in Type 2 diabetes mellitus group symptom ischemia (occlusion or narrowing the blood vessel) causes a lack nutrient and oxygen supply to the heart muscle [24]. T2DM is a major risk factor for the development of CAD [25]. The studies have confirmed that cardiovascular complexities are essentially or partially dependent on sustained chronic hyperglycemia [26]

It is explicit that changes in classical risk factors such as raised blood pressure and abnormal lipids alone cannot describe the excess rate of CAD in patients with type 2 diabetes. In addition, the chronic subclinical vascular inflammation is one of the reasons that play a role in the pathogenesis of CAD, insulin resistance (IR), and T2DM [27]. The markers of subclinical inflammation, include the IL-6, have been shown to be important independent predictors of T2DM and CAD risk [28]. Several studies have reported establish of decreased IGF-1 levels and its relation to insulin sensitivity and to type 2 diabetes. It is well documented that in human patients, low levels of IGF-1 significantly increase the risk for cardiovascular $[18,20]$.

The present study showed increase concentrations of the pro-inflammatory cytokines IL- 6 in the serum of all the tested groups (CAD, T2DM, and CAD and type 2 diabetes together in the same patient groups) compared to the control group. This agrees with previous studies which showed high levels of serum IL-6 in CAD and T2DM patients, compare to controls group [28].

However, lower serum IGF-1 concentrations have been found in patients (CAD, T2DM, and CAD+T2DM) compared with the control group. This agrees with previous several studies which have analyzed the relationship between IGF-I and CAD and T2DM $[18,20]$. There is some contradiction in the findings of the studies; one study found a positive association with reducing serum IGF-1 [21] while the another

Table 5: Correlation between IL-6 and IGF-1 in all the tested groups

\begin{tabular}{lll}
\hline Correlations & & \\
\hline Groups & IGF-1 & IL-6 \\
\hline T2DM & & \\
IGF-1 & 1 & 0.139 \\
IL-6 & 0.139 & 1 \\
CAD & & \\
IGF-1 & 1 & $0.516^{*}$ \\
IL-6 & $0.516^{*}$ & 1 \\
T2DM+CAD & & -0.264 \\
IGF-1 & 1 & 1 \\
IL-6 & -0.264 & \\
\hline
\end{tabular}

${ }^{*}$ Correlation is significant at the 0.05 level (two-tailed). T2DM: Type 2 diabetes mellitus, SD: Standard deviation, CAD: Coronary artery disease, IL-6: Interleukin-6, IGF-1: Insulin-like growth factor

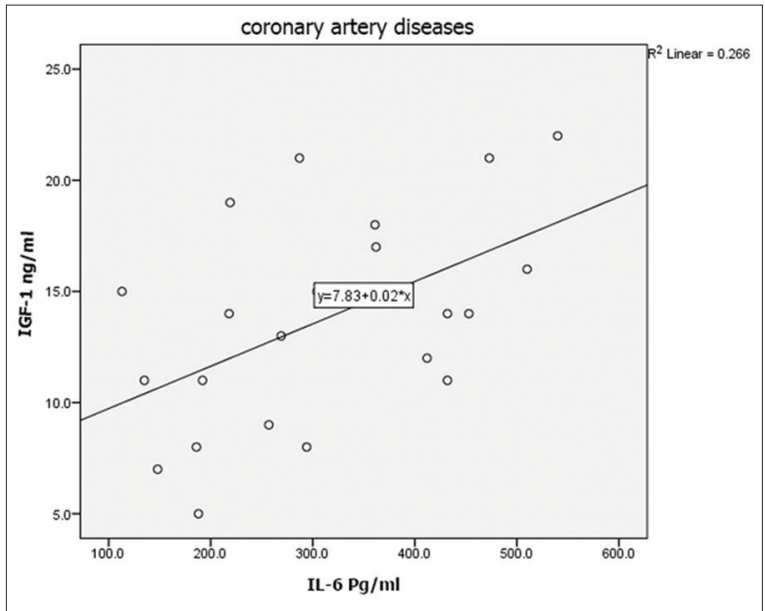

Fig. 2: Correlation between interleukin- 6 and insulin-like growth factor in coronary artery disease group 


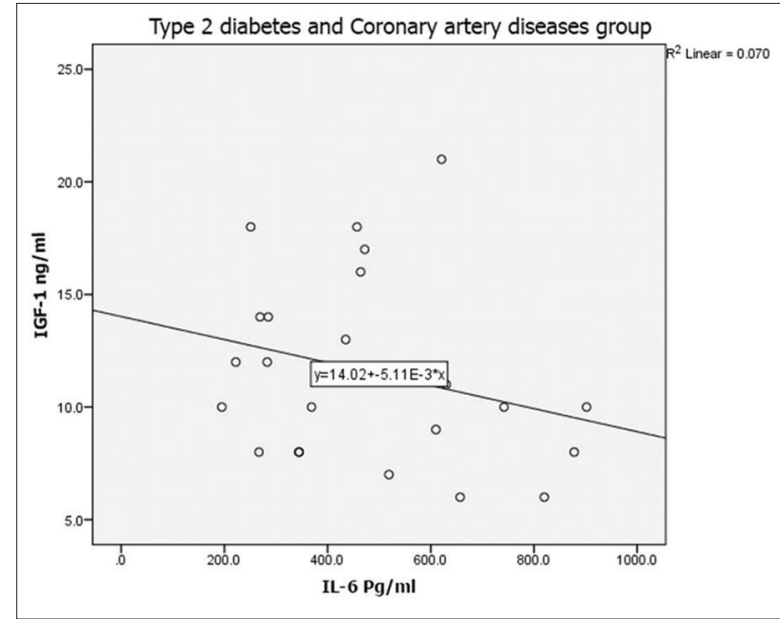

Fig. 3: Correlation between interleukin-6 and insulin-like growth factor in Type 2 diabetes mellitus+coronary artery disease group

study did not find an association [22]. There is a negative relationship between serum IGF-1 levels and risk of developing CAD [18]. In this study, we report a positive correlation among both IL- 6 and IGF in the T2DM group and CAD group, this incompatibility with previous studies but showing a negative correlation in the T2DM+CAD group, this in agreement with study by Succurro et al. [29]. IGF-1 has antiinflammatory effects and lessening expression of pro-inflammatory cytokines like (IL-6) [30]. There are also data in animal models that reports state that IL- 6 reduces IGF-I levels by increasing its clearance [31].

\section{AUTHORS' CONTRIBUTION}

Munther J. and Mohammed Q. run the immunological test by ELISA method and blood sampling and statistical analysis run by Maarib N. All authors contributed ideas and thought to the writing of this paper.

\section{CONFLICTS OF INTEREST}

The authors declare that they have no conflicts of interest.

\section{REFERENCES}

1. Karjalainen J. Cardiovascular Autonomic Function in Coronary Artery Disease Patients With and without Type 2 Diabetes: Significance of Physical Activity and Exercise Capacity. Finland: University of Oulu; 2013.

2. Biondi-Zoccai GG, AbbateA, Liuzzo G, Biasucci LM. Atherothrombosis, inflammation, and diabetes. J Am Coll Cardiol 2003;41:1071-7.

3. Almontashiri NA. The Genetic and Proteomic Detereminants of the Risk of Coronary Artery Disease. Doctoral Dissertation. Canada: Universitéd' Ottawa/University of Ottawa; 2015.

4. Nuramin HW. Effectiveness of ticagrelor compared to clopidogrel in reducing the risk of major adverse cardiovascular events in patients with coronary heart disease after percutaneous coronary intervention. Int J Pharm Pharm Sci 2016;9:178-83.

5. Chatterjee S, Khunti K, Davies MJ. Type 2 diabetes. Lancet 2017;389:2239-51.

6. Kalsi A, Singh S, Taneja N, Kukal S, Mani S. Current treatment for Type2 diabetes, their side effects and possible complementary treatments. Int J Pharm Pharm Sci 2015;3:13-8.

7. Lyssenko V, Jonsson A, Almgren P, Pulizzi N, Isomaa B, Tuomi T, et al. Clinical risk factors, DNA variants, and the development of Type 2 diabetes. N Engl J Med 2008;359:2220-32.

8. Stenlöf K, Cefalu WT, Kim KA, Alba M, Usiskin K, Tong C, et al. Efficacy and safety of canagliflozin monotherapy in subjects with Type 2 diabetes mellitus inadequately controlled with diet and exercise. Diabetes Obes Metab 2013;15:372-82.

9. Alexandraki K, Piperi C, Kalofoutis C, Singh J, Alaveras A, Kalofoutis A, et al. Inflammatory process in Type 2 diabetes: The role of cytokines. Ann N Y Acad Sci 2006;1084:89-117.

10. Kishimoto T. Interleukin-6: Discovery of a pleiotropic cytokine.
Arthritis Res Ther 2006;8 Suppl 2:S2.

11. Palmqvist $P$, Lundberg P, Lundgren I, Hänström L, Lerner UH. IL-1beta and TNF-alpha regulate IL-6-Type cytokines in gingival fibroblasts. J Dent Res 2008;87:558-63.

12. Niu W, Liu Y, Qi Y, Wu Z, Zhu D, Jin W. Association of interleukin-6 circulating levels with coronary artery disease: A meta-analysis implementing Mendelian randomization approach. Int J Cardiol 2012;157:243-52.

13. Lee JK, Bettencourt R, Brenner D, Le TA, Barrett-Connor E, Loomba R, et al. Association between serum interleukin-6 concentrations and mortality in older adults: The rancho bernardo study. PLoS One 2012;7:e34218.

14. Pudil R, Tichý M, Andrýs C, Rehácek V, Bláha V, Vojácek J, et al. Plasma interleukin-6 level is associated with NT-proBNP level and predicts short-and long-term mortality in patients with acute heart failure. Acta Medica (Hradec Kralove) 2010;53:225-8.

15. Omoigui S. The interleukin-6 inflammation pathway from cholesterol to aging -role of statins, bisphosphonates and plant polyphenols in aging and age-related diseases. Immun Ageing 2007;4:1.

16. Mirza S, Hossain M, Mathews C, Martinez P, Pino P, Gay JL, et al. Type 2-diabetes is associated with elevated levels of TNF-alpha, IL-6 and adiponectin and low levels of leptin in a population of Mexican Americans: A cross-sectional study. Cytokine 2012;57:136-42.

17. De Meyts P, Whittaker J. Structural biology of insulin and IGF1 receptors: Implications for drug design. Nat Rev Drug Discov 2002;1:769-83.

18. Ungvari Z, Csiszar A. The emerging role of IGF-1 deficiency in cardiovascular aging: Recent advances. J Gerontol Series A: Biomed Sci Med Sci 2012;67:599-610.

19. Troncoso R, Díaz-Elizondo J, Espinoza SP, Navarro-Marquez MF, Oyarzún AP, Riquelme JA, et al. Regulation of cardiac autophagy by insulin-like growth factor 1. IUBMB Life 2013;65:593-601.

20. Rajpathak SN, Gunter MJ, Wylie-Rosett J, Ho GY, Kaplan RC, Muzumdar R, et al. The role of insulin-like growth factor-I and its binding proteins in glucose homeostasis and Type 2 diabetes. Diabetes Metab Res Rev 2009;25:3-12.

21. Sandhu MS, Heald AH, Gibson JM, Cruickshank JK, Dunger DB, Wareham NJ, et al. Circulating concentrations of insulin-like growth factor-I and development of glucose intolerance: A prospective observational study. Lancet 2002;359:1740-5.

22. Rajpathak SN, McGinn AP, Strickler HD, Rohan TE, Pollak M, Cappola AR, et al. Insulin-like growth factor-(IGF)-axis, inflammation, and glucose intolerance among older adults. Growth Horm IGF Res 2008; 18:166-73.

23. Perkel D, Naghi J, Agarwal M, Morrissey RP, Phan A, Willix RD Jr, et al. The potential effects of IGF-1 and GH on patients with chronic heart failure. J Cardiovasc Pharmacol Ther 2012;17:72-8.

24. Braund PS. Functional Analysis of Novel Genetic Markers of Coronary Artery Disease Identified by Genome-Wide Association Studies (Doctoral dissertation, Department of Cardiovascular Sciences); 2015.

25. Buse JB, Ginsberg HN, Bakris GL, Clark NG, Costa F, Eckel R, et al. Primary prevention of cardiovascular diseases in people with diabetes mellitus: A scientific statement from the American heart association and the American diabetes association. Diabetes Care 2007;30:162-72.

26. Su G, Mi S, Tao H, Li Z, Yang H, Zheng H, et al. Association of glycemic variability and the presence and severity of coronary artery disease in patients with Type 2 diabetes. Cardiovasc Diabetol 2011;10:19.

27. Saito I, Folsom AR, Brancati FL, Duncan BB, Chambless LE, McGovern PG, et al. Nontraditional risk factors for coronary heart disease incidence among persons with diabetes: The atherosclerosis risk in communities (ARIC) study. Ann Intern Med 2000;133:81-91.

28. Pradhan AD, Manson JE, Rifai N, Buring JE, Ridker PM. C-reactive protein, interleukin 6 , and risk of developing Type 2 diabetes mellitus. JAMA 2001;286:327-34

29. Succurro E, Andreozzi F, Sciacqua A, Hribal ML, Perticone F, Sesti G, et al. Reciprocal association of plasma IGF-1 and interleukin-6 levels with cardiometabolic risk factors in nondiabetic subjects. Diabetes Care 2008;31:1886-8

30. Sukhanov S, Higashi Y, Shai SY, Vaughn C, Mohler J, Li Y, et al. IGF-1 reduces inflammatory responses, suppresses oxidative stress, and decreases atherosclerosis progression in apoE-deficient mice. Arterioscler Thromb Vasc Biol 2007;27:2684-90.

31. De Benedetti F, Alonzi T, Moretta A, Lazzaro D, Costa P, Poli V, et al. Interleukin 6 causes growth impairment in transgenic mice through a decrease in insulin-like growth factor-I. A model for stunted growth in children with chronic inflammation. J Clin Invest 1997;99:643-50. 